\title{
Выводы
}

1. Существующая модель развития карстовой системы Ледяной горы на начальном этапе дополнена с позиции особенностей развития гипогенного карста.

2. Фактические данные, полученные в ходе многолетнего эксперимента по изучению растворимости сульфатных отложений в условиях подземных водоемов Кунгурской пещеры, а также современная интерпретация развития органных труб, позволяют определять абсолютный возраст Кунгурской Ледяной пещеры примерно в 10000 лет с разрешением существующих несоответствий по данным изменений значений минерализации подземных вод в различные фазы водности (паводок-межень).

\section{БИБЛИОГРАФИЧЕСКИ СПИСОК}

1. Дорофеев Е.П. Связь водоемов Кунгурской пещеры с рекой Сылвой // Состояние и задачи карстовоспелеологических исследований: тез. докл. Всесоюз. совещ. - Москва, 1975. - С.85-87.

2. Казанцева А.С. Многолетний эксперимент по изучению растворимости сульфатных пород в Кунгурской Ледяной пещере // Вестн. Перм. ун-та. Сер. Геология. - 2018. - Т. 17, № 2. - С. 105-111. DOI: $10.17072 /$ psu.geol.17.2.105.

3. Катаев В.Н. Структурно-тектонические условия формирования Кунгурской пещеры // Пещеры. Итоги исследований: Межвуз. сб.науч. тр. - Пермь, 1993. - Вып.23-24. - С.121-130.

4. Климчук А.Б. Гипогенный спелеогенез, его гидрогеологическое значение и роль в эволюции карста. Симферополь: Изд-во ДИАЙПИ, 2013. - 180 с.

5. Кунгурская Ледяная пещера: опыт режимных наблюдений / под ред. В.Н. Дублянского. Екатеринбург: УрО РАН, 2005. - 376 с.

6. Лукин В.С., Ежов Ю.А. Карст и строительство в районе г.Кунгура. Методика изысканий и опыт строительства в карстовых областях. - Пермь: Кн. изд-во, 1975. - 120 с.: ил.

УДК 069.014

DOI: 10.7242/echo.2019.1.5

\section{НЕКОТОРЫЕ ИТОГИ РАБОТЫ МУЗЕЯ КАРСТА И СПЕЛЕОЛОГИИ В 2017-2018 ГОДАХ}

\author{
Д.В. НАУМКИН, О.И. ОСЕТРОВА \\ Горный институт УрО РАН, г. Пермь
}

\begin{abstract}
Аннотация: Ведомственный музей карста и спелеологии существует при Кунгурской лабораториистационаре Горного института с 2004 г. Его специализация соответствует тематике исследований лаборатории. В статье рассматриваются результаты работы музея за 2017-2018 гг. по основным направлениям, которые являются общими для всех музейных учреждений страны: экспозиционная, выставочная, фондовая, экскурсионная и издательская деятельность. В течение отчетного периода завершено оформление постоянной экспозиции музея; модифицированы экспозиционные площади выставочного зала; проведено 9 временных выставок, в т.ч. привезенных из других музеев и от частных коллекционеров. Общий фонд поставленных на первичный музейный учет предметов составляет 4126 единиц хранения (2085 основного и 2041 - вспомогательного фонда). В 2018 г. начат второй (тематический) учет экспонатуры. Посещаемость находится на уровне, характерном для муниципальных музеев г. Кунгура - 19 тыс. посетителей за два года. 75\% посетителей - дети. География экскурсионных групп - в основном города и регионы Урала и Сибири (Пермь, Челябинск, Екатеринбург, Тюмень, Омск, Новосибирск, и др.), а также Киров, Казань, Москва, Петербург, Самара, Нижний Новгород, Ижевск. В настоящее время музей стал востребованным и популярным объектом припещерной инфраструктуры.
\end{abstract}

Ключевые слова: музей карста и спелеологии; постоянная экспозиция; выставочный зал; музейные фонды; экскурсии; посещаемость.

В течение 2017-2018 гг. музей карста и спелеологии осуществлял деятельность по нескольким основным направлениям, общим для работы всех музейных учреждений страны. 
Экспозиционная деятельность. В 2018 г. была завершена работа над созданием постоянной экспозиции музея. Она приобрела, наконец, законченный вид. Работа шла над оформлением ее центрального раздела, посвященного Кунгурской Ледяной пещере. Под эту тему была отведена витрина размерами 2,3х3,1 м с экспозиционной площадью 4,9 м $^{2}$. Минералогическая основа раздела представлена очень показательно: в экспозиции использованы 44 минералогических образца практически из всех гротов пещеры (37 из них - сульфаты, 3 - карбонаты и 4 - бораты). Образцы подбирались, исходя из их максимальной аттрактивности, размера, либо уникальности.

Остальные подтемы, освещенные в экспозиции, посвящены истории изучения и экскурсионного благоустройства и животному миру пещеры. Для показа широко использованы плоскостные иллюстративные материалы (фотографии, план пещеры, книги, тетрадь для записей метеонаблюдений (1934 г.), записная книжка В.С. Лукина с метеоданными из пещеры (1935 г.), инструкция по изучению пещерного льда, разработанная проф. Г.А. Максимовичем (1946 г.)). Из этой же категории замечательный экспонат - французская гравюра первой четверти XVIII в., изображающая план Кунгурской Ледяной пещеры С.У. Ремезова. Гравюра была выставлена на аукционе в г. Минске и приобретена Горным институтом в 2005 г. [1].

Животный мир пещеры, хоть и относительно небогатый, представлен отдельным комплексом материалов. В первую очередь это сухой препарат наиболее знаменитого и интересного пещерного обитателя - крангоникса Хлебникова. Другой натурный экспонат - почти полный скелет глухаря, найденный в гроте Полярном во время глобальной очистки пещеры от антропогенного мусора.

Внимание посетителей неизменно привлекают огромная лампа накаливания и светильник из грота Длинный, которые еще недавно использовались для освещения пещеры. Насыпанные в стеклянный мерный цилиндр ржавые монетки из Большого подземного озера - последнее свидетельство и следствие давней многолетней традиции (которую культивировали сами экскурсоводы): бросить монетку в озеро в память о пребывании в пещере. Слой монет у берега в гроте Хлебниковых достиг к началу XXI столетия полуметра! Среди полностью проржавевших советских и российских копеек и рублей попадаются немецкие пфеннинги (ГДР) и дойчмарки (ФРГ), чехословацкие кроны, болгарские левы, монгольские тугрики и украинские копийки.

Еще один экспозиционный проект, завершенный в 2018 г., это модернизация раздела «Палеонтология» в выставочном зале музея. Еще недавно палеонтологические экспонаты демонстрировались здесь в трех небольших витринах, вмещавших совсем немного образцов. Новую большую (3 м) витрину со встроенной подсветкой изготовила фирма «ЦТО» (г. Пермь). Экспонаты в ней размещаются на стеклянных полках, разноуровневых подставках и подиумах, крепятся к задней стенке. Самые древние разделы геохронологической шкалы (венд, кембрий, ордовик, силур) представлены единичными образцами (немианы, трилобиты, ортоцератиды). Довольно разнообразно представлена морская фауна беспозвоночных девона [2], карбона и перми. Много места занимают превосходные образцы пермской фауны головоногих (наутилоидеи и гониатиты) из Красноуфимского района Свердловской обл. (дар О.В. Абросимовой), а также образцы с отпечатками растительности кунгурского века пермского периода $\left(\mathrm{P}_{1} \mathrm{k}\right)$, собранные на знаменитом местонахождении Чекарда [3]. В целом больше половины витрины приходится на палеозой.

Мезозойские образцы представлены также морской фауной беспозвоночных - в основном аммонитами, белемнитами и двустворками. Среди них абсолютно преобладают юрские виды, меньше - меловых, а триас представлен очень бедно 
(отпечатки раковин Monotis sp., Крым). Из палеогена кайнозоя происходят пресноводная рыбка Diplomistus sp. (Вайоминг, США), креветка Aeger libanensis (Ливан) [4], крымские устрицы и фрагменты окаменевшей древесины из Поволжья. Квартер представлен остатками млекопитающих мамонтовой фауны.

Оформляя витрину, мы использовали минимум изображений-реконструкций, стремясь поместить как можно больше натурных этикетированных образцов. Неоценимую помощь в их идентификации оказал д.г.-м.н., проф. С.В. Наугольных (Геологический институт РАН). Целый ряд изображений-реконструкций был включен в эскиз огромной $(3,5$ м) геохронологической шкалы, которая разместилась на стене над витриной. Разработка эскиза и его информационное наполнение выполнено аспирантом А.В. Красиковым. К сожалению уже после реализации этого проекта выявился ряд ошибок и неточностей, в том числе в использовании строго регламентированной цветовой гаммы. Тем не менее в настоящее время палеонтологический раздел выставочного зала приобрел совершенно другой вид. Надо отметить, что посетители музея теперь подолгу разглядывают и витрину, и цветную геохронологическую шкалу.

Фондовая работа. Богатство любого музея - его фонды. В течение 2017-18 гг. на музейный учет поставлено в общей сложности 308 единиц хранения основного и 411 единиц хранения вспомогательного фонда. Всего таким образом на музейном учете сегодня находится 4126 единиц хранения (2085 основного и 2041 вспомогательного фонда). Многолетняя динамика поступлений отражена на рис. 1.

Источники поступлений - полевые сборы сотрудников, подарки от посетителей и коллег из различных музеев. Поступающие в течение года экспонаты ставятся на первичный учет в основной или вспомогательный фонд музея в хронологическом порядке; каждой коллекции присваивается очередной номер сквозной нумерации. Коллекция в данном случае выступает единицей учета - она может содержать как единственный (одиночный) образец, так и множество экспонатов. В течение 2017-18 гг. на поступившие музейные предметы было составлено 23 коллекционных описи. Ниже кратко охарактеризованы некоторые наиболее интересные коллекции и экспонаты.

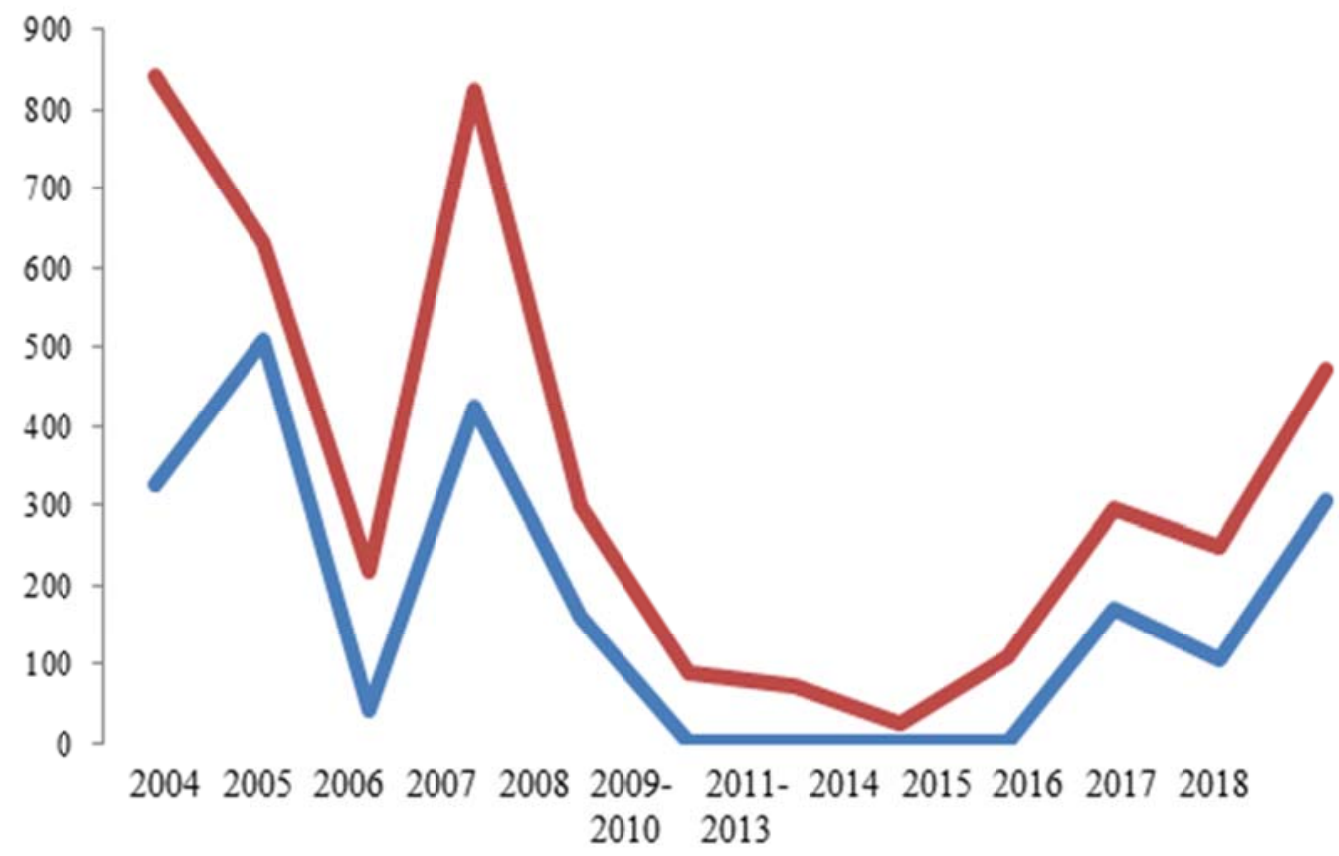

Рис. 1. Динамика поступлений экспонатов в музей карста и спелеологии (красный цвет - вспомогательный фонд; синий - основной фонд) 
Замечательная по разнообразию и качеству образцов минералогическая коллекция поступила из музея им. А.Е. Ферсмана РАН от к.г.-м.н. А.В. Касаткина [5]. Она включает образцы из России, Мексики, Испании, США и Туркмении. Все они представлены очень аттрактивными разностями. Это в первую очередь агрегаты кристаллов кальцита, сфалерита и андрадита с различных месторождений Приморья (Дальнегорское, Боросиликатное, Синереченское), пиритовые конкреции (Татарстан и Ульяновская обл.), азурит с малахитом из Кемеровской обл. (Каменушинское месторождение), оригинальный глендонит - беломорская «рогулька» (псевдоморфоза кальцита по икаиту) с Терского берега (Мурманская обл.). Оживление среди посетителей вызывает минерал кридит (рудник Абасоло, штат Дуранго, Мексика). Он относится к классу фторидов, единственным представителем которых в нашей коллекции был флюорит. Мексиканский кридит представлен округлым агрегатом разноцветных кристаллов. Не менее любопытен кристалл тенардита (озеро Сёрзл, пустыня Мохаве, Калифорния, США). Этот представитель сульфатов был знаком нам ранее лишь как эфемер, периодически образующийся в гротах Кунгурской Ледяной пещеры [6-7] и совершенно не поддающийся музейному показу. Пещерные минералы карбонатной группы - кальцит и арагонит - представлены образцами из пещер Туркмении (Кап-Кутан) и Испании (Ла-Пескуера).

Очень интересные и разнообразные сборы палеонтологического материала из Крыма подарила музею студентка МГУ Л.Ю. Кадебская. Возраст находок охватывает временной интервал от позднего триаса $\left(\mathrm{T}_{3} \mathrm{n}\right)$ до эоцена $\left(\mathrm{Pg}_{2} \mathrm{i}\right)$. В основном это двустворчатые моллюски, которых до этого практически не было в фондах музея. Наиболее древние - отпечатки створок монотисов Monotis sp. в сером алевролите $\left(\mathrm{T}_{3} \mathrm{n}\right)$. Крупная эффектная устрица Pycnodonte rarilamella и более мелкие раковины устриц Pycnodonte antiqua представляют крымский палеоцен $\left(\mathrm{Pg}_{1} \mathrm{t}\right)$. Также в сборах присутствуют двустворки Catoceramus buguntaensis, Plagiostroma marrotiana, Amphidonta decussate, устрицы Pycnodonte vesiculare, гребешки Microchlamys acuteplicata. Все они обитали у побережья Крыма в верхнем мелу ( $\left.\mathrm{K}_{2} \mathrm{~km}-\mathrm{m}\right)$. Дополняют картину сборы брюхоногих, брахиопод-теребратулид (некоторые из которых (Terebratula mishensis, T. plana) относятся к позднему палеоцену), белемнитов и кораллов, а также характернейших для Крыма нуммулитов (монеток) Nummulites distans, N. polygyratus, N. globules ( $\left.\mathrm{Pg}_{2} \mathrm{i}\right)$. Все образцы подробно этикетированы, так как собраны в рамках студенческой практики геологического факультета МГУ. Часть коллекции представлена в выставочном зале на постоянной основе, из остальных экспонатов в перспективе возможна организация тематической выставки, посвященной палеонтологии и геологии Крыма.

В 2017 г. сотрудники нашего института впервые поработали на знаменитых стерлитамакских шиханах Башкирии: Тратау, Юрактау и Шахтау. Сборы д.г.н. О.И. Кадебской, к.г.-м.н. Н.В. Лавровой и А.А. Верхоланцева включают брахиопод, мшанок, кораллы Protowentzelella simplex $\left(\mathrm{P}_{1} \mathrm{~s}\right)$ [8] и моллюсков. Наиболее эффектный образец - крупный кусок известняка, буквально «нашпигованный» раковинами наутилоидей, некоторые из которых достигают 10-12 см в диаметре.

В 2017-2018 гг. палеонтологическое собрание музея существенно пополнилось крупными аттрактивными образцами благодаря нашим коллегам из г. Красноуфимска (Свердловская обл.). В окрестностях этого города широко представлены памятники древней морской жизни, относящиеся к нижнему отделу пермской системы ( $\left.\mathrm{P}_{1} \mathrm{ar}\right)$. Несмотря на то, что рифовые постройки артинского возраста есть и в окрестностях Кунгура, видовой состав красноуфимских местонахождений существенно отличается от кунгурских наличием крупных брахиопод-продуктид, крупных криноидей, поздних трилобитов, а также специфичным саргинско-саранинским комплексом головоногих, 
которые почти не представлены в ближайших окрестностях Кунгура. В результате собственных сборов и щедрых даров О.В. Абросимовой в фондах музея появилась коллекция, включающая губок, брахиопод, двустворок, трилобита Ditomopyge artinskiensis, крупные эффектные раковины гониатит родов Uraloceras и Paragastrioceras, наутилоидеи Metacoceras sp. (рис. 2).

Пещерная минерализация, в силу специфики нашего музея, представлена в нем очень разнообразно. Предварительный обзор вторичных карбонатных образований из пещер был сделан в 2016 г., сегодня их насчитывается 150 единиц хранения [9]. Почти половина образцов (48,3\%) приходится на Дивью пещеру - длиннейшую на Северном Урале. В 2018 г. в фонды музея поступили обширные сборы из пещер Урала (от Северного до Южного), использованные О.И. Кадебской как натурный материал для защиты докторской диссертации. 30 образцов из 14 пещер отобраны в основной фонд и предназначены для демонстраций, 101 хранится во вспомогательном фонде для возможных исследований в будущем. Очевидно с этих сборов в перспективе начнется комплектование раздела монографических коллекций в фондах музея.

Великолепными экспонатами пополнилось художественное собрание музея. Свои авторские работы из талькохлорита, выполненные в жанре анималистики («Мышьмалютка на гнезде», «Барсучок»), подарил известный художник-камнерез из с. Красный Ясыл (Ординский район) С.О. Нечаев. Гипсолитные изделия (модельный гипс) кунгурского производства 1950-60-х гг. передали М.С. Пятунин, Н.Н. Козлова и коллеги из Кунгурского музея (отреставрированная скульптурная композиция «Серый Волк и Красная Шапочка»). Исключительную по красоте и ценности работу уральскую горку из минералов - подарила в начале 2018 г. О.В. Абросимова (рис. 3). Горка изготовлена ею собственноручно из различных минералов: гранатов (альмандинов), кварца и актинолита с Шабровского месторождения, змеевика и кальцита, собранных в окрестностях г. Красноуфимска, кристаллов прозрачного гипса с месторождения Ундоры (Ульяновская обл.). В настоящее время горка демонстрируется в выставочном зале музея.

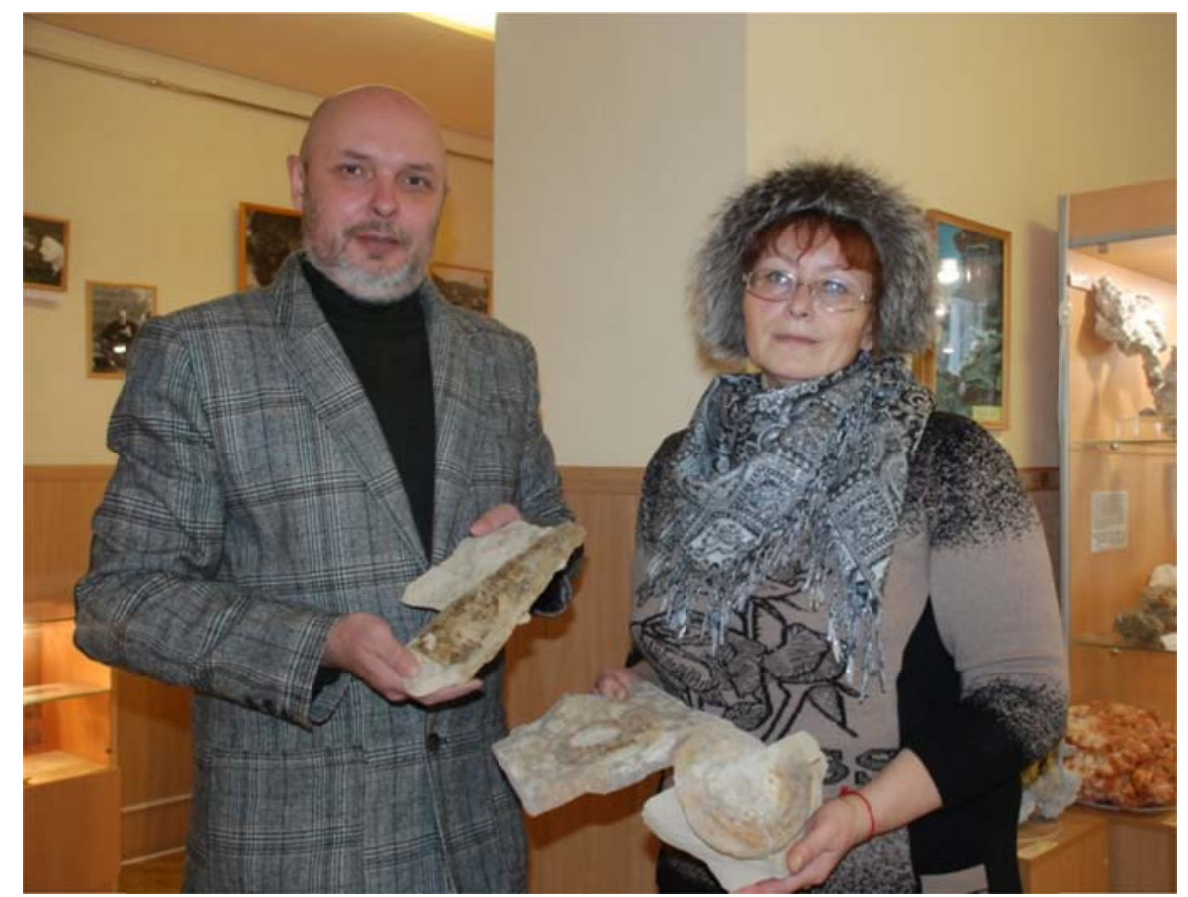

Рис. 2. О.В. Абросимова с подаренными ею раковинами головоногих: прямая наутилоидея (слева) и гониатиты (справа). 2018 г. 
Фондовая работа включает в себя обработку, систематизацию, перевод в цифровой формат многочисленных личных фото и документов сотрудников Кунгурского стационара, ставших известными геологами-карстоведами. Одним из наиболее изученных и структурированных личных фондов музея карста и спелеологии является фонд Вячеслава Семеновича Лукина. В 2018 г. именно с него начался второй (тематический) учет экспонатуры вспомогательного фонда, куда относятся, главным образом, фотодокументальные материалы. В настоящее время известно, что личный фонд В.С. Лукина включает 294 единицы хранения различных категорий (фото, документы, книги, газеты и журналы, фалеристика, быт, и пр.), в т.ч. 175 документов и 49 фотографий. Второй учет прошли материалы В.П. Дорофеева, Д.В. Рыжикова и А.В. Турышева, а также материалы (главным образом, цветная полиграфия), относящиеся к экскурсионным пещерам Европы и США. Прошедшие второй учет экспонаты хранятся по системе, принятой в архивных учреждениях страны.

В конце 2018 г. помещения фондохранилища были оборудованы современными металлическими стеллажами, что позволило оптимально разложить коллекции и составить топографические описи их размещения.

Выставочная и экскурсионная деятельность. Возможности выставочной деятельности в музее объективно ограничены из-за его малой площади. Тем не менее, небольшой выставочный раздел для демонстрации сменных выставок оборудован в привходовой зоне музея. За отчетный период здесь было оформлено 9 временных выставок, в том числе новых поступлений за 2017 и 2018 гг., палеонтологических образцов из фондов музея, выставки, посвященные 30-летию Ассоциации спелеологов Урала [10] и 80-летию Кунгурской лаборатории-стационара. Дважды проводились выставки уральских мастеров-камнерезов, где были представлены их творческие работы. Выставка «Птицы Ледяной горы» построена в содружестве с Кунгурским музеем (рис. 4), выставка морских и пресноводных раковин - на основе частных коллекций.

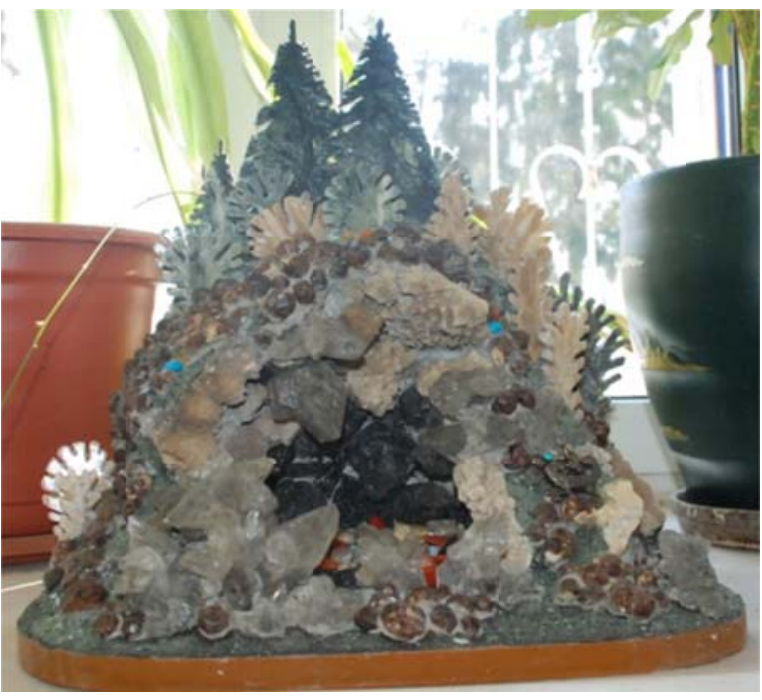

Рис. 3. Уральская горка из минералов. 2017 г.

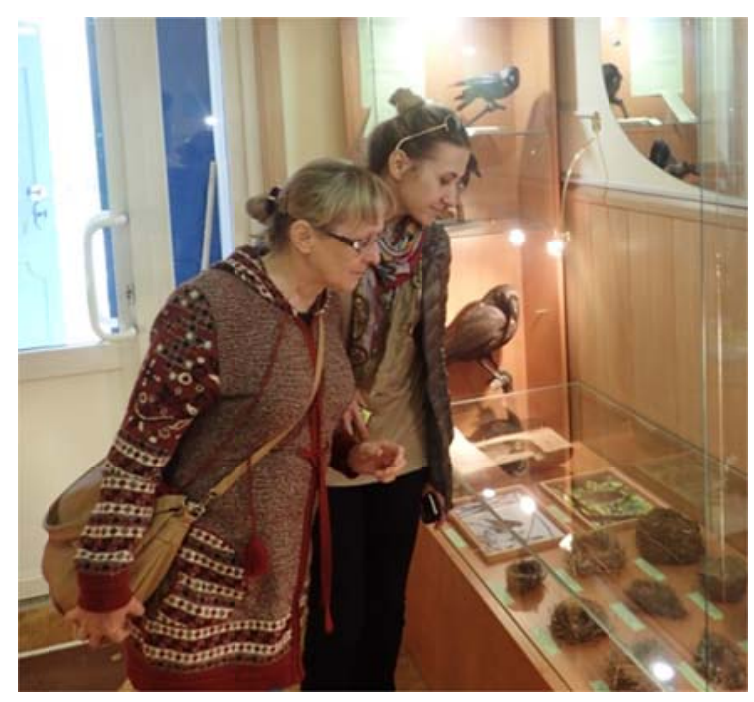

Рис. 4. Выставка «Птицы Ледяной горы». 2018 г.

Постоянная выставка горных пород и минералов, располагающаяся в выставочном зале, насчитывает сегодня 672 экспоната, размещенных в 10 витринах и на подиумах по принципам минералогической систематики. В течение 2017-2018 гг. в выставочном зале были оформлены новые витрины с палеонтологией и уральской яшмой. 
Общее количество посетителей музея за два года составило около 19 тысяч человек, примерно 75\% из которых - дети. География экскурсионных групп - в основном города и регионы Урала и Сибири (Пермь, Челябинск, Екатеринбург, Тюмень, Омск, Новосибирск, и др.), а также Киров, Казань, Москва, Петербург, Самара, Нижний Новгород, Ижевск. Основной проблемой в обслуживании туристических групп является их излишняя многочисленность (группы более 20 человек в залы музея просто не помещаются), а также неравномерность турпотока, связанная с аналогичным параметром Кунгурской пещеры - в «высокий» сезон (весенние каникулы) наблюдается перезаполненность музейных площадей и возрастает экскурсионная нагрузка на сотрудников.

Издательская деятельность. В 2017-2018 гг. статьи сотрудников музея на музейную тематику были опубликованы в Москве, Миассе, Красноуфимске (рис. 5), Новосибирске и Томске.

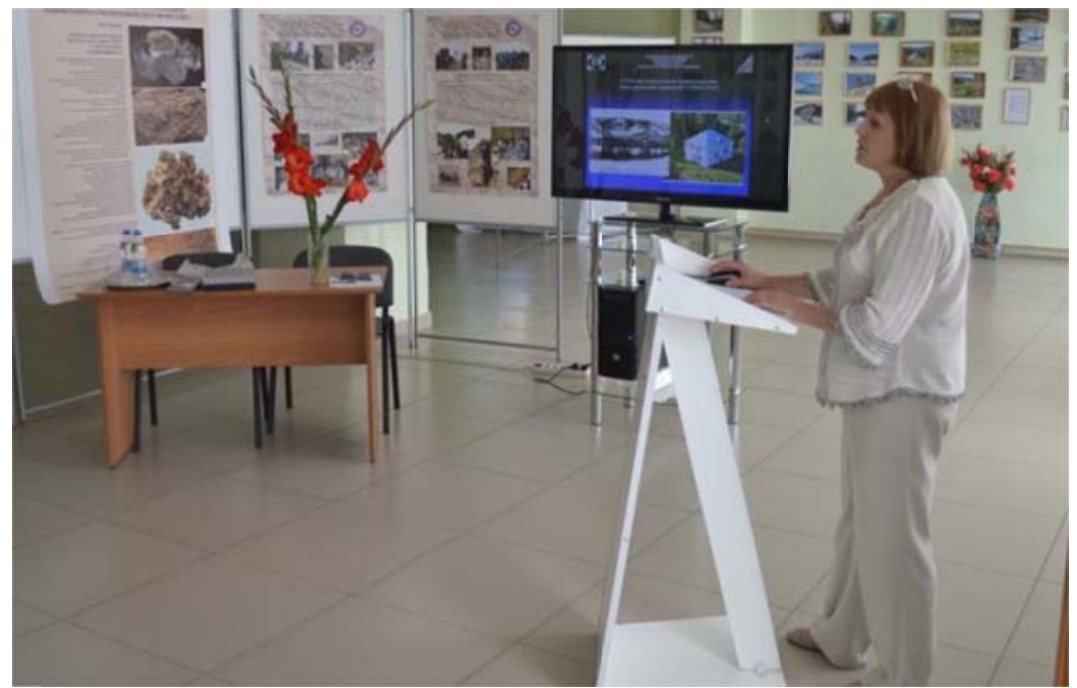

Рис. 5. О.И. Осетрова на конференции в г. Красноуфимске доклад о Е.П. Дорофееве. 2017 г.

\section{БИБЛИОГРАФИЧЕСКИЙ СПИСОК}

1. Наумкин Д.В. Французская гравюра в фондах Музея карста и спелеологии ГИ УрО РАН (первый план Кунгурской Ледяной пещеры С.У. Ремезова) // Пещеры. - Пермь: ПГУ, 2008. - Вып. 31. - С. 195-197.

2. Осетрова О.И., Наумкин Д.В. Тиманская коллекция в фондах музея карста и спелеологии Горного Института Уральского отделения РАН // Палеоэкология. Методологические оснювы, фактологический потенциал, применение в музейных экспозициях. - М., 2017. - С. 18-21.

3. Наумкин Д.В. Коллекция Пермской флоры в музее карста и спелеологии Горного института УрО РАН // Стратегия и процессы освоения георесурсов: материалы Всерос. науч. конф. / ГИ УрО РАН. Пермь, 2008. - С. 61-62.

4. Наумкин Д.В. Новые поступления в палеонтологическую коллекцию Музея карста и спелеологии ГИ УрО РАН // Грибушинские чтения - 2007. - Кунгур, 2007. - С. 187-188.

5. Наумкин Д.В. Новые поступления в минералогическую коллекцию музея карста и спелеологии Горного института УрО РАН // Минералогия техногенеза. - 2018. - № 19. - С. 249-252.

6. Андрейчук В.Н., Кадебская О.И., Чайковский И.И. Криогенные минеральные образования Кунгурской Ледяной пещеры / Силезский ун-т, ГИ УрО РАН. - Сосновец; Пермь, 2013. - 128 с.

7. Лаврова Н.В. Сульфатные минералы пещер // Кунгурская Ледяная пещера: 300 лет научной и туристической деятельности. - Пермь, 2003. - С. 95-97.

8. Кулагина Е.И., Скуин И.А., Коссова О.Л. Пермский риф Шахтау. - Уфа: Белая река, 2015. - 72 с.

9. Наумкин Д.В., Осетрова О.И. Кальцитовые минеральные образования пещер в фондах музея карста и спелеологии ГИ УрО РАН (обзор коллекции) // Пещеры. - Пермь, 2016. - Вып. 39. - С. 68-72.

10. Наумкин Д.В. Кунгурский стационар Горного института УрО РАН и Ассоциация спелеологов Урала: 30 лет сотрудничества // Минералогия техногенеза. - 2018. - № 19. - С. 253-258. 